\title{
KANDUNGAN LEMAK DAN KOMPOSISI ASAM-ASAM LEMAK PADA BAGIAN BADAN IKAN JULUNG-JULUNG (Hemiramphus brasiliensis)
}

\author{
Louisa M.F Josephus $^{1 *}$, Julius Pontoh ${ }^{1}$ dan Lidya I. Momuat ${ }^{1}$ \\ ${ }^{1}$ Jurusan Kimia Fakultas Matematika dan Ilmu Pengetahuan Alam Universitas Sam Ratulangi, \\ Jl. Kampus Unsrat, Kleak, Manado 95115 Sulawesi Utara
}

\begin{abstract}
ABSTRAK
Telah dilakukan penelitian mengenai kandungan lemak dan komposisi asam-asam lemak pada bagian badan ikan julung-julung. Penentuan kadar lemak pada penelitian ini menggunakan metode ekstraksi pemanasan dengan air (wet rendering). Kadar lemak pada bagian badan ikan julung-julung yaitu 0,02\%. Ekstrak lemak ikan yang diperoleh di transesterifikasi basa menggunakan metode derivatisasi kemudian diinjeksikan pada alat kromatografi gas. Hasil penelitian ini menyimpulkan bahwa asam-asam lemak utama yang ada pada bagian badan ikan julung-julung adalah asam palmitat dan DHA. Sedangkan untuk asam-asam lemak omega-3 yang diperoleh yaitu asam eikosatrienoat, EPA dan DHA, dengan total kandungan omega-3 pada bagian badan yaitu $27,0 \%$.
\end{abstract}

Kata kunci: ikan julung-julung, asam lemak omega-3, kromatografi gas

\section{ABSTRACT}

Research has been conducted for the fat content and composition of fatty acids in the part of body of the julungjulung fish. Determination of fat content in this study using the method of water heating extraction (wet rendering). Fat content in the part of body of the julung-julung fish is $0.02 \%$. The extract of fish fat was transesterified bases using the derivatization method and then injected on a gas chromatography device. The results of this study prove that the main fatty acids present in the part of body of the julung-julung fish are palmitic acid and DHA. As for the omega-3 fatty acids obtained, namely eicosatrienoic acid, EPA and DHA, with the total omega-3 content in the part of body is $27.0 \%$.

Keywords: Julung-julung fish, omega-3 fatty acids, gas chromatography

\section{PENDAHULUAN}

Laut Indonesia merupakan salah satu sumber kekayaan alam yang melimpah dengan jenis ikan yang beraneka ragam (Dotulong dkk., 2018). Ikan merupakan salah satu sumber makanan utama yang sangat baik dan prospektif (Panagan dkk., 2011).

Ikan dari perairan laut dibedakan atas ikan pelagis dan ikan karang. Menurut Handoyo (2011), ikan pelagis adalah kelompok ikan yang sebagian besar hidupnya berada pada lapisan permukaan hingga pertengahan kolom air (mid layer). Ikan pelagis memiliki ciri khas dalam beraktivitas yakni selalu membentuk gerombolan (schooling) dan melakukan migrasi untuk berbagai kebutuhan hidupnya (Simbolon, 2011). Ikan pelagis dibagi dalam dua kelompok yaitu, ikan pelagis besar, contohnya ikan cakalang dan ikan pelagis kecil, contohnya ikan julung-julung.
Kedua ikan tersebut sangat digemari oleh masyarakat khususnya di daerah Sulawesi Utara.

Ikan merupakan makanan fungsional karena mengandung asam-asam lemak omega3. Asam-asam lemak omega-3 yang dikenal yaitu asam linolenat, asam eikosapentaenoat atau EPA, dan asam dokosaheksaetanoat atau DHA (Suwetja, 2011). Asam-asam lemak ini mempunyai fungsi biologis yang dapat meningkatkan kesehatan otak, penglihatan (mata) dan mencegah penyakit pembuluh darah (aterosklerosis). Jenis makanan seperti ini dinamakan makanan fungsional (Kaur dkk., 2012).

Komposisi kimia ikan sangat bervariasi, baik antar jenis satu dengan yang lain, antar individu dalam satu jenis, atau bahkan antar bagian-bagian tubuh dalam satu individu. Variasi itu disebabkan oleh adanya perbedaan jenis ikan, umur, ukuran, jenis kelamin, musim dan suhu

\footnotetext{
Korespondensi:

Telepon: +62 852-5605-5130

Email: louisajosephus21@gmail.com

DOI: https://doi.org/10.35799/cp.12.2.2019.27309
} 
perairan saat ikan ditangkap (Suwetja, 2011). Pada penelitian sebelumnya oleh Paramudhita (2014), didapatkan komposisi asam lemak total pada ikan cakalang segar sebesar $0,6 \%$ dengan 30 jenis asam lemak, diantaranya 12 jenis SFA (saturated fatty acid), 7 jenis MUFA (mono unsaturated fatty acid) dan 11 jenis PUFA(Poly unsaturated fatty acid).

Menurut Pontoh (2019), total kandungan lemak untuk ikan segar utuh adalah $0,41 \%$. Kandungan lemak tertinggi pada ikan gabus berada pada bagian kepala $(63,8 \%)$ diikuti oleh jeroan $(19,9 \%)$ dan perut $(16,3 \%)$. Komposisi asam lemak dari lemak yang terdapat pada bagianbagian tubuh ikan berbeda-beda satu dengan yang lain.

Penentuan asam lemak dalam minyak ikan biasanya dilakukan dengan teknik kromatografi gas. Asam lemak dalam minyak ikan diubah terlebih dahulu dari triasilgliserol atau trigliserida menjadi metil ester asam lemak dengan metode derivatisasi (Ackman, 1982). Metode derivatisasi merupakan proses kimiawi untuk mengubah suatu senyawa menjadi senyawa lain yang mempunyai sifat-sifat yang sesuai untuk dilakukan analisis menggunakan kromatografi gas (Gandjar \& Rohman, 2012). Keunggulan penggunaan metode kromatografi gas dapat mendeteksi sampai pada jumlah nanogram, resolusi tinggi serta jumlah sampel yang di butuhkan sedikit (Gritter, 1991). Penelitian ini bertujuan untuk menentukan kandungan lemak dan komposisi asam lemak omega-3 pada bagian badan ikan pelagis khususnya ikan julung-julung yang ada di perairan Manado dan sekitarnya.

\section{BAHAN DAN METODE}

\section{Alat dan bahan}

Alat-alat yang digunakan yaitu, pisau, talenan, blender chopper, kompor gas, panci stainless steel, botol transparan $600 \mathrm{~mL}$, kaca arloji, pipet tetes, tabung reaksi, sentrifugasi, botol vial, corong, timbangan analitik, aluminium foil, tisu, pipet volumetrik, labu takar, gelas ukur dan seperangkat alat kromatografi gas Shimadzu (GC2014). Bahan-bahan yang digunakan yaitu, sampel ikan pelagis ( bagian badan ikan julungjulung) yang diperoleh dari Pasar Tradisional Bersehati di kota Manado, metanol, $\mathrm{NaOH}$, aquades, heksan, asam asetat dan Supelco 37 Component FAME Mix (standar).

\section{Ekstraksi dan penetapan kadar lemak}

Sampel ikan diangkut ke tempat pemrosesan kemudian dipotong dan diambil bagian badan kemudian diblender. Sampel yang sudah diblender dipindahkan ke panci stainless steel dan ditambahkan air 2 kali volume sampel. Sampel direbus selama sekitar 1 jam dan ditambahkan air untuk menjaga volume air konstan. Selanjutnya sampel dibiarkan dingin, diambil kaldu hangatnya kemudian dimasukkan ke dalam botol transparan $600 \mathrm{~mL}$ dengan leher sempit panjang. Setelah kaldu berada di dalam botol, fraksi lemak menumpuk di bagian atas kaldu. Lemak disalurkan ke tabung sentrifugasi $15 \mathrm{~mL}$ kemudian disentrifugasi selama 15 menit pada $1000 \mathrm{rpm}$. Lemak dipisahkan dan dikumpulkan untuk analisis lebih lanjut. Kandungan lemak dihitung sebagai berat lemak dibagi dengan berat sampel segar waktu 100\% (Pontoh, 2019). Kadar lemak dapat dihitung dengan rumus:

$$
\% \text { Total lemak }=\frac{\text { berat lemak }}{\text { berat sampel }} \times 100 \%
$$

\section{Penetapan kadar air}

Sebanyak 3g sampel (daging ikan julungjulung) dimasukkan ke dalam oven pada suhu $105^{\circ} \mathrm{C}$ selama 3-5 jam, kemudian dikeluarkan dari oven dan didinginkan dalam desikator selama 30 menit, setelah itu sampel ditimbang. Perlakuan ini dilakukan beberapa kali hingga berat sampel konstan. Kadar air dihitung berdasarkan rumus:

$$
\% \text { kadar air }=\frac{a-b}{a} \times 100 \%
$$

Keterangan: $\mathrm{a}=$ berat awal sampel, $\mathrm{b}=$ berat akhir sampel

\section{Derivatisasi asam lemak}

Derivatisasi asam lemak mengikuti prosedur Christie (1989). Sampel lemak ikan sebanyak 50 mg dilarutkan dalam $1 \mathrm{~mL}$ heksan kemudian ditambahkan $2 \mathrm{~mL} \mathrm{0,5} \mathrm{M} \mathrm{NaOH}$ dalam metanol, selanjutnya dipanaskan selama 10 menit pada suhu $50^{\circ} \mathrm{C}$, didinginkan lalu ditambahkan $0,1 \mathrm{~mL}$ asam asetat dan $5 \mathrm{~mL}$ aquades. Larutan sampel didiamkan selama beberapa menit dan terbentuk 2 lapisan, lapisan atas dimasukkan ke dalam botol vial, dan lapisan bawah diekstrak kembali dengan heksan sebanyak 2 kali dengan masing-masing volume $5 \mathrm{~mL}$. Lapisan atas yang terbentuk diambil dan di masukkan ke dalam botol vial yang berbeda. Dari setiap botol diambil sebanyak $1 \mu \mathrm{L}$ untuk dianalisis di kromatografi gas. 


\section{Analisis kromatografi gas}

Analisis kromatografi dilakukan menggunakan Shimadzu Gas Chromatography (GC-2014) dengan Flame Ionization Detector (FID) dan kolom Thermo Scientific (TR-FAME) dengan panjang $30 \mathrm{~m}$, diameter $0,25 \mathrm{~mm}$, ketebalan film $0,25 \mu \mathrm{m}$. Suhu kolom dari $120^{\circ} \mathrm{C}$ selama 7 menit lalu meningkat sampai $250^{\circ} \mathrm{C}$ dengan jalannya suhu $10{ }^{\circ} \mathrm{C} /$ menit dan dipertahankan selama 20 menit suhu konstan sebesar $250{ }^{\circ} \mathrm{C}$. Suhu detektor adalah $270{ }^{\circ} \mathrm{C}$. Suhu injeksi dipanaskan pada $260{ }^{\circ} \mathrm{C}$, dilengkapi dengan injektor split-pisah dengan $1 / 10$ dan tekanan gas pembawa helium diatur pada $75 \mathrm{kPa}$. $1 \mu \mathrm{L}$ sampel dimasukkan ke tempat injeksi. (Pontoh, 2016)

\section{Penentuan kandungan asam lemak}

Waktu retensi asam-asam lemak pada minyak ikan ditentukan berdasarkan waktu retensi asam-asam lemak Supelco 37 Component FAME Mix (standar) (Khan, 2013). Komposisi asamasam lemak ditentukan berdasarkan jumlah luas puncak metil ester asam-asam lemak dibagi total luas puncak dikali $100 \%$. Rumus persen luas puncak:

$\frac{\text { Luas puncak metil ester asam-asam lemak }}{\text { Total luas puncak asam-asam lemak }} \times 100 \%$

\section{HASIL DAN PEMBAHASAN}

\section{Kadar air dan lemak}

Pengujian kadar air dilakukan untuk mengetahui banyaknya kadar air dari sampel. Nilai rata-rata kadar air pada bagian badan ikan julungjulung yaitu $75,9 \%$. Kadar air dalam produk perikanan diperkirakan sebesar 70-85\% (Nurjanah \& Abdullah, 2010). Menurut Buckle dkk. (1987), pengaruh kadar air sangat penting dalam menentukan daya awet suatu bahan pangan karena kadar air mempengaruhi sifat-sifat fisik (organoleptik), sifat kimia, dan kebusukan oleh mikroorganisme. Untuk nilai kadar lemak pada bagian badan ikan julung-julung yaitu $0,02 \%$. Untuk bagian badan, faktor utama perbedaan kadar lemak ikan dapat dipengaruhi oleh jenis ikan, kebiasaan makan, kedewasaan, musim dan ketersediaan pakan (Nianda, 2008). Kadar air dan kadar lemak sangat berfluktuasi. Jika kandungan lemak pada daging semakin besar, kandungan air akan semakin kecil dan sebaliknya (Irianto \& Giyatmi, 2015).

Faktor lain yang menyebabkan kadar lemak pada ikan rendah adalah metode yang digunakan untuk mengekstrak. Pada penelitian asam lemak sebelumnya, Sari dkk. (2018) menggunakan ekstraksi soxhletasi dengan pelarut kimia seperti metanol dan kloroform sehingga kadar lemak yang didapat lebih tinggi, sedangkan pada penelitian ini ekstraksi yang digunakan hanya pemanasan (rendering) dengan air mendidih. Hasil pengujian kadar air dan kadar lemak pada bagian badan ikan julung-julung dapat dilihat pada Tabel 1.

Tabel 1. Nilai kadar air dan lemak pada badan ikan julung-julung

\begin{tabular}{lc}
\hline \multicolumn{1}{c}{ Pengujian } & Ikan julung-julung \\
\hline Kadar air $(\%)$ & $75,90 \% \pm 0,45$ \\
Kadar lemak $(\%)$ & $0,02 \% \pm 0,00$ \\
\hline
\end{tabular}

\section{Asam-asam lemak}

Penentuan asam-asam lemak dalam lemak ikan ditentukan berdasarkan waktu retensi asamasam lemak Supelco 37 Component FAME Mix sebagai standar yang terdapat pada Gambar 1.

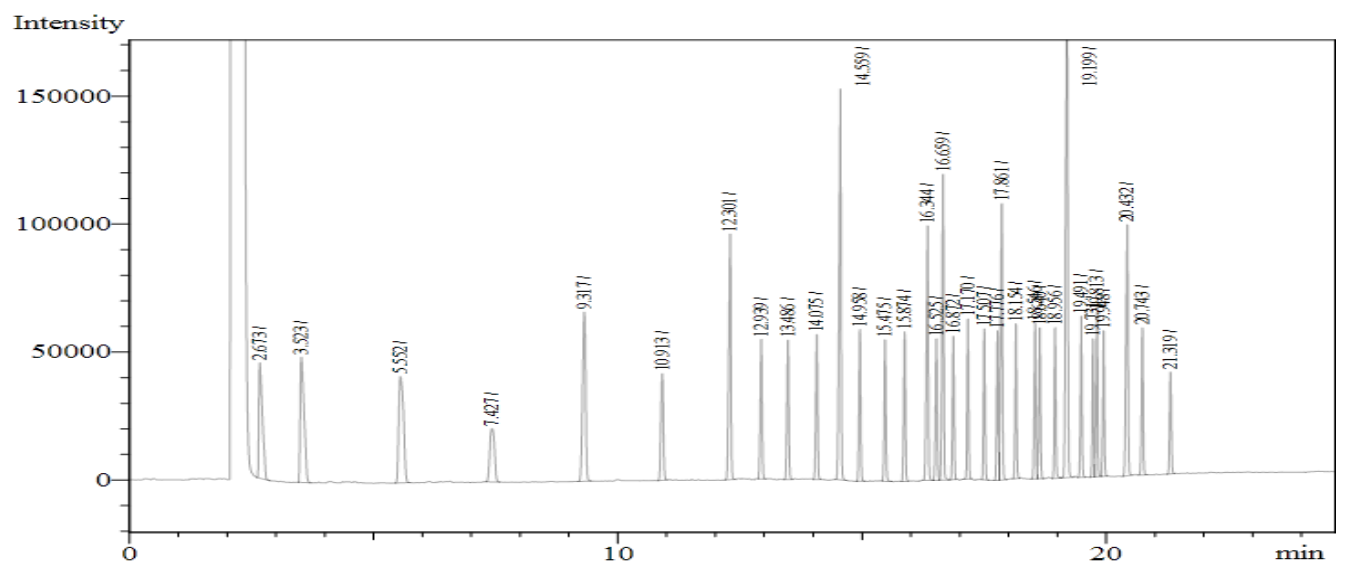

Gambar 1. Kromatogram Supelco FAME mix (Standar) 
Hasil kromatogram menunjukkan bahwa puncak-puncak yang muncul terpisah dengan baik sehingga dapat digunakan sebagai panduan untuk menentukan asam-asam lemak apa saja yang terdapat dalam sampel. Dari 37 puncak, secara kasat mata hanya 34 puncak yang dibaca. Hal ini karena ada 3 puncak yang tumpang tindih. Kromatogram ini, sesuai dengan hasil analisis sebelumnya oleh Khan (2013) yang menggunakan kolom dan standar yang sama.

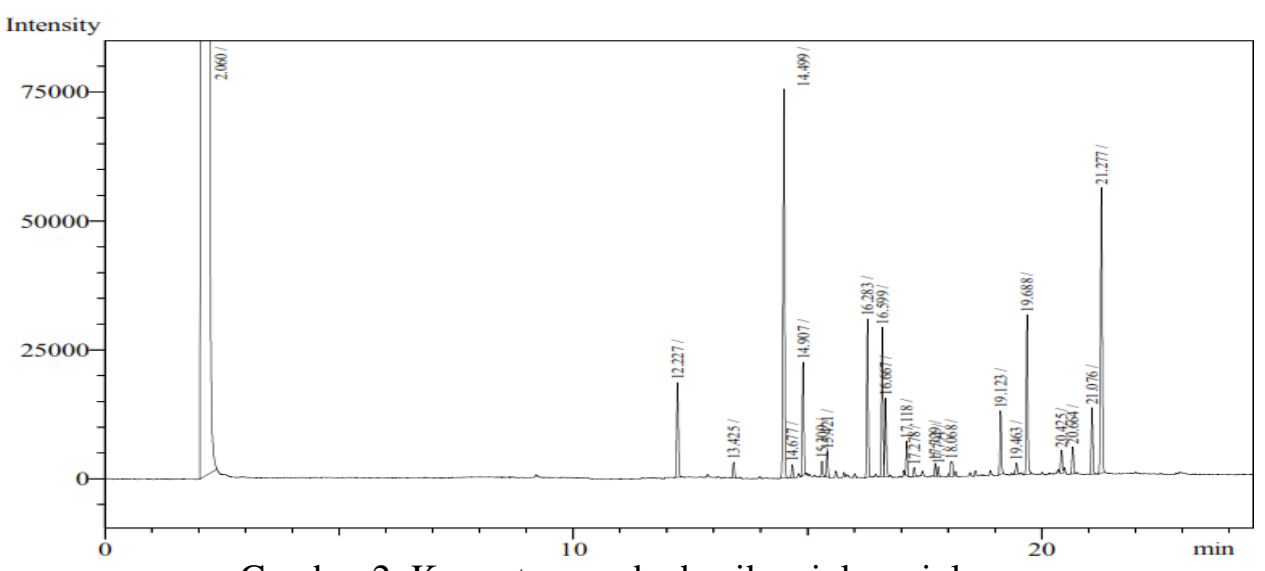

Gambar 2. Kromatogram badan ikan julung-julung

Kromatogram Gambar 2 adalah hasil analisis asam-asam lemak yang ada pada bagian badan ikan julung-julung. Berdasarkan waktu retensi asam-asam lemak dengan menggunakan standar FAME mix, didapatakan 17 jenis asam lemak yaitu C16:0, C22:6, C18:0, C18:1 C, C23:0, C14:0, C16:1, C18:2 T, C20:3 C ${ }^{*}$ C24:1, C18:2 C, C17:0, C20:5*, C15:0, C20:1, C18:3 Cis 6, dan C20:4 (dalam Tabel 1). Komposisi asam lemak pada ikan ditentukan oleh beberapa faktor yaitu spesies, musim, letak geografis, tingkat kematangan (umur) dan jenis makanan yang dikonsumsi ikan tersebut (Saito $d k k$., 1997). Dengan demikian, dapat dikatakan ikan yang hidup di setiap daerah memiliki perbedaan komposisi asam lemak.

\section{Profil asam lemak}

Kandungan asam-asam lemak pada bagian badan ikan julung-julung dapat dilihat pada Tabel 1. Asam palmitat adalah asam lemak yang paling banyak terdapat pada ikan julung-julung. Tiga jenis asam lemak dengan kandungan paling tinggi pada bagian badan ikan julung-julung masingmasing adalah asam palmitat $(24,2 \%)$ sebagai asam lemak dengan kandungan paling tinggi, diikuti DHA $(22,5 \%)$ dan stearat $(9,8 \%)$. Tingginya asam palmitat pada ikan sesuai dengan pernyataan Osman $d k k$., (2001), yakni palmitat merupakan asam lemak jenuh yang paling banyak terdapat dalam lemak ikan.Total SFA pada bagian badan yaitu $49,8 \%$. Jenis SFA yang paling tinggi pada bagian tubuh ikan julung-julung adalah asam palmitat. Jumlah asam palmitat pada bagian badan ikan julung-julung yaitu 24,2\%. Ozugul (2007), menambahkan bahwa kadar asam palmitat dari keseluruhan asam lemak jenuh mencapai 53-63\%.

Tabel 2. Profil asam lemak dalam badan Ikan julung-julung

\begin{tabular}{|c|c|c|}
\hline \multirow[b]{2}{*}{ Asam Lemak } & \multirow[b]{2}{*}{ Nama } & Julung-Julung \\
\hline & & $\begin{array}{c}\text { Badan } \\
\%(w / w)\end{array}$ \\
\hline C14:0 & Miristat & $6,0 \pm 0,2$ \\
\hline C15:0 & Pentadekanoat & $1,3 \pm 0,3$ \\
\hline C16:0 & Palmitat & $24,2 \pm 0,5$ \\
\hline $\mathrm{C} 17: 0$ & Heptadekanoat & $1,8 \pm 0,3$ \\
\hline C18:0 & Stearat & $9,8 \pm 0,9$ \\
\hline C23:0 & Trioksanoat & $6,7 \pm 2,3$ \\
\hline Total SFA & & 49,8 \\
\hline C16:1 & Palmitoleat & $5,0 \pm 1,3$ \\
\hline $\mathrm{C} 18: 1 \mathrm{C}$ & Oleat & $8,3 \pm 0,2$ \\
\hline C20:1 & Eikosanoat & $1,1 \pm 0,6$ \\
\hline C24:1 & Nervonat & $2,0 \pm 0,3$ \\
\hline Total MUFA & & 16,4 \\
\hline $\mathrm{C} 18: 2 \mathrm{~T}$ & Linolelaidat & $3,8 \pm 0,6$ \\
\hline $\mathrm{C} 18: 2 \mathrm{C}$ & Linoleat & $1,8 \pm 0,1$ \\
\hline C18:3 CIS 6 & $y$-Linolenat & $0,9 \pm 0,2$ \\
\hline C20:3 C* & Eikosatrienoat & $3,0 \pm 0,6$ \\
\hline C20:4 & Arakidonat & $0,8 \pm 0,0$ \\
\hline $\mathrm{C} 20: 5^{*}$ & EPA & $1,5 \pm 0,0$ \\
\hline C22:6* & DHA & $22,5 \pm 3,8$ \\
\hline Total PUFA & & 34,3 \\
\hline Total Omega-3 & & 27,0 \\
\hline
\end{tabular}

Total MUFA pada bagian badan yaitu $16,4 \%$. Asam oleat adalah MUFA dengan kadar tertinggi. Jumlah asam oleat pada bagian badan 
ikan julung-julung yaitu 8,3\%. Hal ini sesuai dengan pernyataan Ozugul (2007), yang menyatakan asam oleat merupakan asam lemak paling banyak dalam asam lemak jenuh tunggal pada lemak ikan yaitu $52-79 \%$ dari total asam lemak tak jenuh tunggal.

Total PUFA pada bagian badan yaitu 34,3\%. DHA adalah PUFA dengan kadar terbanyak pada ikan ini. Asam lemak PUFA didalamnya mengandung asam lemak omega-3 yang bermanfaat bagi kesehatan. Total omega-3 pada bagian badan ikan julung-julung sebanyak $27,0 \%$. DHA memiliki peran penting pada omega3. Kandungan DHA pada bagian badan ikan julung-julung yaitu $22,5 \%$.

Minyak ikan akan sangat bermanfaat bagi kesehatan apabila minyak tersebut kaya akan asam lemak omega-3 seperti EPA dan DHA (Haris, 2004). Penelitian omega-3 menunjukkan bahwa DHA penting bagi perkembangan manusia sejak awal dimana DHA merupakan komponen penting dalam pertumbuhan jaringan otak (Rasyid, 2003). Kekurangan asam lemak omega-3 dapat menimbulkan gangguan saraf dan penglihatan serta bisa mengganggu perkembangan sistem saraf. Akibatnya, bisa menyebabkan gangguan pada sistem daya tahan tubuh, daya ingat, mental dan penglihatan (Diana, 2012).

\section{KESIMPULAN}

Nilai kadar lemak pada bagian badan ikan julung-julung yaitu $0,02 \%$. Asam-asam lemak utama penyusun lemak pada bagian badan ikan julung-julung adalah asam palmitat $(24,2 \%)$ sebagai asam lemak dengan kadar lemak paling tinggi diikuti DHA (22,5\%). Sedangkan asamasam lemak omega-3 yang ada pada ikan julungjulung adalah asam eikosatrienoat, EPA dan DHA, dengan total kandungan omega-3 yaitu 27,0\%.

\section{DAFTAR PUSTAKA}

Ackman, R.G. 1982. Fatty acid composition in fish oil. Bandung: Academic Press.

Buckle, K.A., Edwards, R.A., Fleet, G.H. \& Wooton, M. 1987. Ilmu pangan. Terjemahan Hari Purnomo. Jakarta: Universitas Indonesia.

Christie, W.W. 1989. Gas chromatography and lipids: A practical guide. Scotland: The Oily Press.
Diana, M.F. 2012. Omega-3. Jurnal Kesehatan Masyarakat. 6(2), 113-117.

Dotulong, V., Patty, C.N. \& Suwetja, I.K. 2018. Mutu ikan roa (Hemirhamphus sp.) asap yang dijual di pasar bersehati kota manado sulawesi utara. Jurnal Media Teknologi Hasil Perikanan. 6(3), 281-286.

Gandjar, I.G. \& Rohman, A. 2012. Analisis obat secara spektroskopi dan kromatografi. Yogyakarta: Pustaka Pelajar.

Gritter, J.R., James, M., Bobbit. \& Arthur, E. 1991. Pengantar kromatografi. Bandung: ITB.

Hadiwiyoto. 1993. Teknologi pengolahan hasil perikanan. Yogyakarta: Liberty.

Handoyo, K. 2011. Sistem informasi pengelolaan sumberdaya dan lingkungan perikanan tangkap di Kabupaten Padang Pariaman, Sumatera Barat. Bogor: Institut Pertanian Bogor.

Haris, W.S. 2004. Review: Fish oil supplementation: evidence for health benefits. Cleveland Clinic Journal of Medicine. 71(3), 208-219.

Irianto, H.E. \& Giyatmi, S. 2015. Prinsip dasar teknologi pengolahan hasil perikanan. Banten: Universitas Terbuka.

Kaur, N., Chugh, V. \& Gupta, A.K. 2012. Essential fatty acids as functional components of foods a review. Journal Food Science Technology. 51(10), 22892303.

Khan, I.K. 2013. A GC-FID method for the comparison of acid and base-catalyzed derivatization of fatty acids to fames in three edible oils. Runcorn UK: Thermo fisher Scientific.

Nianda, T. 2008. Komposisi protein dan asam amino daging ikan gurami (Osphronemus gouramy) pada berbagai sumur panen. Program Studi Teknologi Hasil Perikanan Fakultas Perikanan dan Ilmu Kelautan Institut Pertanian Bogor, Bogor.

Nurjanah \& Abdullah, A. 2010. Cerdas memilih ikan dan mempersiapkan olahannya. Bogor (ID): IPB Press.

Osman, H., Suriah, A.R. \& Law, E.C. 2001. Fatty acid composition and cholesterol content of selected marine fish in malaysian water. Food Chemistry. 73(6), 55-60.

Ozugul, Y. \& Ozugul, F. 2007. Fatty acid profiles of commercially important fish species from 
the mediterranean, agean dan black seas. Food Chemistry. 100(4), 1634-1638.

Panagan, A.T., Yohandini, H. \& Gultom, J.U. 2011. Analisis kualitatif dan kuantitatif asam lemak tak jenuh omega-3 dari minyak ikan patin (Pengasius pangasius) dengan metode kromatografi gas. Jurnal Penelitian Sains. 14(4), 39-42.

Paramudhita, P.S. 2014. Perubahan komposisi asam lemak dan kolesterol ikan cakalang (Katsuwonus pelamis) akibat proses penggorengan. Fakultas Perikanan dan Ilmu Kelautan. Bogor: Institut Pertanian Bogor.

Pontoh, J. 2016. Gas chromatographic analysis of medium chain fatty acids in coconut oil. Journal of Pure and Applied Chemistry Research. 5(3), 157-161.

Pontoh, J. 2019. Extraction and characterization of fish oil from various parts of snakehead fish (Chana striate). International Journal of ChemTech Research. 12(1), 323-328.
Rasyid, A. 2003. Asam lemak omega-3 dari minyak ikan. Oseana. 28(3), 11-16.

Saito, H., Ishihara, K. \& Murase, T. 1997. The fatty acid composition in tuna (Bonito, Eutynus Pelamis) caught at tree defferent localities from tropics to temperate. Journal of the Science Food and Agriculture. 73(1), 53-59.

Sari, I.P., Pontoh, J. \& Sangi, M.S. 2018. Komposisi kimia asam-asam lemak pada daging ikan teri (Stophelorus sp.). Chemistry Progress. 12(2), 30-36.

Simbolon, D. 2011. Bioekologi dan dinamika daerah penangkapan ikan. Departemen Pemanfaatan Sumberdaya Perikanan. Fakultas Perikanan dan Ilmu Kelautan. Bogor: Institut Pertanian Bogor.

Suwetja, I.K. 2011. Biokimia hasil perikanan. Jakarta: Media Prima Aksara. 